Número 1, febrero 2012. No 01/01.

\title{
The Geographical Distribution of the Personal Networks of People Living in Catalonia: a dual society ${ }^{1}$
}

José Luis Molina*, Carlos Lozares Colina** \& Miranda J Lubbers*.(UAB)

\section{Abstract}

Based on a survey concerning personal networks of a sample of 416 people living in Catalonia we address two questions: First, are there differences between native-born and foreign-born residents in terms of the geographical repartition of their personal networks? Second, regarding active contacts providing support, where do they live?

Our data show that on average $70 \%$ of the active contacts of native-born residents live in the same city whereas immigrants have more than $50 \%$ of their active contacts living in another city or country, regardless of the length of residence in Catalonia. Natives and immigrants also differ in the location of supportive network contacts, mostly non-locals in the latter case.

With regard to the social interactions among nationals and immigrants, our results bring us to characterize the Catalan society as a "dual society", with a social divide between the two groups. We suggest that this situation can be applicable to most of the countries where a "sub-functional class" is working in a dual labour market

\section{Introduction}

Thanks to the widespread use of mobile phones, GPSs, bluetooth devices and internet resources as Googlemaps (among others), ubiquitous geographic information is now widely available for social research. In the case of the literature that pays attention to the collection and analysis of geographical information related to social interactions we find contributions in the field of Epidemiology (Obbo, 1993,

\footnotetext{
1 Research project funded by the MICINN (CSO2008-01470/SOCI), Estudio comparado de casos sobre la influencia mútua entre el capital e integración sociales y la inserción, estabilidad, promoción y cualificación en el empleo. PI: Carlos Lozares Colina, QUIT, Department of Sociology, UAB.

* Department of Social and Cultural Anthropology - EgoLab-Grafo (UAB). ** Department of Sociology - QUIT - Institut d'Estudis del Treball,
} 
Número 1, febrero 2012. No 01/01.

Chen et al., 2007), Economic Geography (Glückler, 2007), travelling (Larsen et al., 2006, Carrasco et al., 2008; Frändberg, 2008; Urry 2010), phone calls (Onnela et al., 2007; Lambiotte et al., 2008; Licoppe et al., 2008) and Small-World simulations (Liben-Nowell et al., 2005), among others. In our case, the concept of "personal network geography" (Axhausen, 2008) is especially useful because it combines the information about active contacts of a given respondent with the current residence of each network contact in the geographic space.

In this article we explore the spatial dimension of personal networks of a sample of the Catalan population focusing specifically on the relationships among native-born ("national") and foreign-born residents ("immigrants") and the location of their supportive network contacts. Thus, our research questions are the following:

- Are there differences between "nationals" and "immigrants" in terms of the geographical distribution of their personal networks?

- Where do the support-providing contacts of nationals and immigrants live?

These questions are part of the research agenda launched in 1976 by Fischer (1982) and Wellman (1979) looking for responses to the "Community Question", namely, if changes in "modern" societies, especially concerning urbanization and transport, affect the social support available to individuals. Catalonia has only become an important destination area for migrants in the last ten years, so it is of interest to investigate how this development affects the social interactions and social support of the Catalan population. Fischer and Wellman proposed to answer these questions by measuring the size, composition and structure of the personal networks of people, and relating them to geographic distance, ways of travel and communication. More recently, Grossetti (2007) applied Fischer's design in Toulouse (France) in order to compare results cross-nationally. This rich literature has shown that social support is still available in the cities in both sides of the Atlantic (although it was possible to find variation in density in the case of Israel and USA, see Fischer \& Shavit, 1995). Regarding the geographical distribution of personal networks, Hampton and Wellman (2002) coined the term "glocalization" to describe the characteristic distribution of personal networks in space, being most of the contacts available on a short radius but with a part of them spread throughout the World. Grossetti (2007) investigated the influence of mobility on social support, and found that it takes two years for 
Número 1, febrero 2012. No 01/01.

people who moved to another place of residence to build up a local network, and five years to build up a local network as big as that of locals. Grossetti focused in particular on intranational mobility, whereas our study distinguishes between intra- en international migration.

Our contribution to this literature is threefold: First, we enlarged the compositional and structural information available for each individual about her strong and weak ties. We elicited a list of 30 network contacts ("alters") from each respondent ("ego") with a flexible name generator (see below for details) and we asked respondents about the attributes of alters and the relationships among alters, so compositional (attributes) and structural (network) information about both strong and weak ties are available in our data. Previous studies tended to elicit the names of fewer alters, a higher proportion of strong ties, and less structural information (because questions about alter-alter relationships were restricted to a subsample of important alters).

Second, thanks to the geographic tools available on the internet we are able to map the location of non-local alters (people living in a different city or town than the respondent), in order to visualize the "glocalization" phenomenon. This visualization shows variation between groups and helped us to elicit new hypotheses (Brandes et al., 2006).

Finally, we are interested in the comparison among nationals and immigrants in terms of their personal networks and the social interactions among them. The results of our analysis has led us to characterize the Catalan society as a "dual society", with a social divide between nationals and immigrants regardless of the years of residence of the latter. We suggest that this situation can be applicable to most of countries where a "sub-functional class" (Galbraith, 1992) is working in a dual labour market (Piore, 1972).

\section{Data}

The data is part of a survey launched by the ongoing research project CASCIVI (2009-2011, see note 1 and Lozares et al., in press), regarding social cohesion, social capital and personal networks in Catalonia, an autonomous region in the north east of Spain. The data collection has two phases: The first phase consists of the elicitation of personal networks of a quota sample of the Catalan population. In the 
Número 1, febrero 2012. No 01/01.

second phase, in-depth interviews were conducted with selected respondents. The personal network data phase (including the pilot test) was carried out mostly during the second semester of 2009 and the first of 2010 by the research team. In this article we draw on the personal network data $(N=416)$.

\section{Sampling strategy}

In order to obtain a first overview of the personal networks of the Catalan population, a quota sampling strategy was used. The sampling strategy was based on two axes, time and space. The time axe concerns the different migratory waves that explain the current composition of the Catalan population, starting with (1) people older than 55 years, who were born in Catalonia and whose parents were also born in Catalonia and (2) people younger than 55 years born in Catalonia and with parents born in Catalonia. The other target groups are (3) people older than 55 born in the rest of Spain, (4) people born in Catalonia with at least one parent born in the rest of Spain, and two of the main groups of immigrants living in Catalonia: (5) Moroccans and (6) Ecuadorians.

Catalonia received a strong migratory wave during the late 50s and 60s (hence the group of people older than 55 born in the rest of Spain). Also, the "second generation" of these migrants is represented (people born in Catalonia with at least one parent born in the rest of Spain). During the late 80s and 90s the first Moroccans arrived. They are currently the largest migrant group, who made up $19 \%$ of the total migrant population in Catalonia in 2009 , and about $16 \%$ of the total migrant population in the province of Barcelona (IDESCAT 2009). Finally, only very recently (2000-2004), Ecuadorians started to migrate in larger numbers to Catalonia. Ecuadorians now make up $7 \%$ of the total migrant population in Catalonia (being the third largest group of migrants) and $9 \%$ of the migrant population in the province of Barcelona (the second largest group).

Taking into account these population groups, the distribution of interviews is shown in Table 1. 
Número 1, febrero 2012. No 01/01.

\begin{tabular}{|l|c|c|c|}
\multicolumn{1}{|c|}{ Target groups } & $\boldsymbol{N}$ & $\%$ & $\begin{array}{c}\text { Cumulative } \\
\%\end{array}$ \\
\hline Age>55, born in Catalonia with parents born in Catalonia & 92 & 22,1 & 22,1 \\
\hline Age 25-55, born in Catalonia with parents born in Catalonia & 56 & 13,5 & 35,6 \\
\hline Age>50, born in the rest of Spain & 63 & 15,1 & 69,0 \\
\hline $\begin{array}{l}\text { Age 25-55, born in Catalonia, with parents born in the rest of } \\
\text { Spain }\end{array}$ & 76 & 18,3 & 53,8 \\
\hline Born in Ecuador & 56 & 13,5 & 82,5 \\
\hline Born in Morocco Total & 73 & 17,5 & 100,0 \\
\hline \multicolumn{1}{c|}{ T16 } & $\mathbf{1 0 0 , 0}$ & \\
\hline
\end{tabular}

Table 1. Target groups, representing migratory waves in Catalonia including "locals".

The second axis represents the geographical distribution of the population in Catalonia, and more specifically in the province of Barcelona - one of the four provinces of Catalonia. The province is basically formed by Barcelona city (approximately 2 million inhabitants), the Metropolitan Area of Barcelona (AMB, with 3,2 million inhabitants in total, including the city of Barcelona) and the rest of the province (in total 5,5 million people). To represent the three types of regions, respondents were selected in Barcelona city, Sant Feliu de Llobregat (AMB) and Balaguer (a small town in the rural area with 16,000 inhabitants). Within each locality, respondents from the 6 targets groups were interviewed.

\begin{tabular}{|l|c|c|c|c|}
\hline \multicolumn{1}{|c|}{ Target Groups } & \multicolumn{4}{c|}{ Place of residence } \\
\cline { 2 - 5 } & Barcelona & St. Feliu & Balaguer & Total \\
\hline $\begin{array}{l}\text { Age>55, born in Catalonia with parents born in } \\
\text { Catalonia }\end{array}$ & 35 & 33 & 24 & 92 \\
\hline $\begin{array}{l}\text { Age 25-55, born in Catalonia with parents born in } \\
\text { Catalonia }\end{array}$ & 16 & 17 & 23 & 56 \\
\hline $\begin{array}{l}\text { Age>50, born in the rest of Spain } \\
\text { Age-25-55, born in Catalonia, with parents born in } \\
\text { the rest of Spain }\end{array}$ & 27 & 22 & 27 & 76 \\
\hline Born in Morocco & 25 & 24 & 24 & 73 \\
\hline Born in Ecuador & 24 & 19 & 13 & 56 \\
\hline \multicolumn{1}{|c|}{ Total } & 149 & 134 & 133 & $\mathbf{4 1 6}$ \\
\hline
\end{tabular}


Número 1, febrero 2012. No 01/01.

Table 2. Number of respondents within each of the target groups and its distribution over the places of residence.

Overall, gender is distributed approximately 50-50 in each target group $(50,2 \%$ males and $49,8 \%$ females). Only in the case of Moroccans there are significantly more males $(58 \%)$ than females, representing the gender distribution of Moroccans in Catalonia (59\%, IDESCAT 2009).

Measures

Personal network elicitation. The personal networks were collected with the aid of EgoNet ${ }^{2}$. EgoNet is a questionnaire authoring language structured in four modules: (1) questions about ego, (2) name(s) generator for generating alters, (3) questions about those alters, and (4) questions about the existence of relationships between alters.

In our case, each of the 416 egos nominated 30 alters using a free listing name generator looking for active contacts and, within the description of each alter, her geographical location was recorded. The name generator was formulated as follows:

"Please write down a list of 30 people who you know by name and who know you by name, with whom you have had contact in the last two years by any means of communication, and who could be contacted again if necessary. Do not include people under 18 .

These people can be anyone. Try to include people who are close and important to you. Then you can include people whom you are not accustomed to be so close with or to see much. You can expand your memory to others. It may help to think of different groups of people in different places, family, friends, colleagues, neighbours... Enter the name and last name in abbreviated form so that only you can recognize people. It is important not to abbreviate too much to recognize them later. For example: Mig Cerv by Miguel de Cervantes."

This flexible name generator (free-recall method, McCarty, 2002) combined with a large list of people, forces individuals to explore sets of people to whom they are

\footnotetext{
${ }^{2}$ http://sourceforge.net/projects/egonet
} 
Número 1, febrero 2012. No 01/01.

connected in different social settings and in different ways, so a realistic sample of the personal networks surrounding every individual is captured. This information, combined with the relationships in alter-alter pairs gives an accurate map of ego's personal network (Molina et al. in press).

The geographical distribution of personal networks. To investigate the geographical distribution of the personal networks, respondents were asked to indicate the locality of every alter nominated. After normalization, we calculated the longitude and latitude of each alter (GPSvisualizer ${ }^{3}$ ) and generated the maps (Googlemaps ${ }^{4}$ ) for each target group.

\section{Results}

Social relationships of people born in Catalonia are essentially local: In general, over $70 \%$ of the contacts live in the same city or area of influence, confirming the "glocalization" phenomenon described by Hampton and Wellman (2002) among others Figure 1 shows the distribution of the non-local contacts jointly for all nativeborn respondents. With the aim of simplifying the exposition, only target group 4 is shown (people born in Catalonia with at least one parent born in the rest of Spain; $N$ $=76$ ), because there is little variation in the pattern of distribution with the other national groups except for this group having more active contacts in the rest of Spain. In the figures, each node refers to a single location in which at least one of the alters lives.

\footnotetext{
${ }^{3} \mathrm{http}: / /$ www.gpsvisualizer.com

${ }^{4}$ http://maps.google.es
} 
Número 1, febrero 2012. No 01/01.
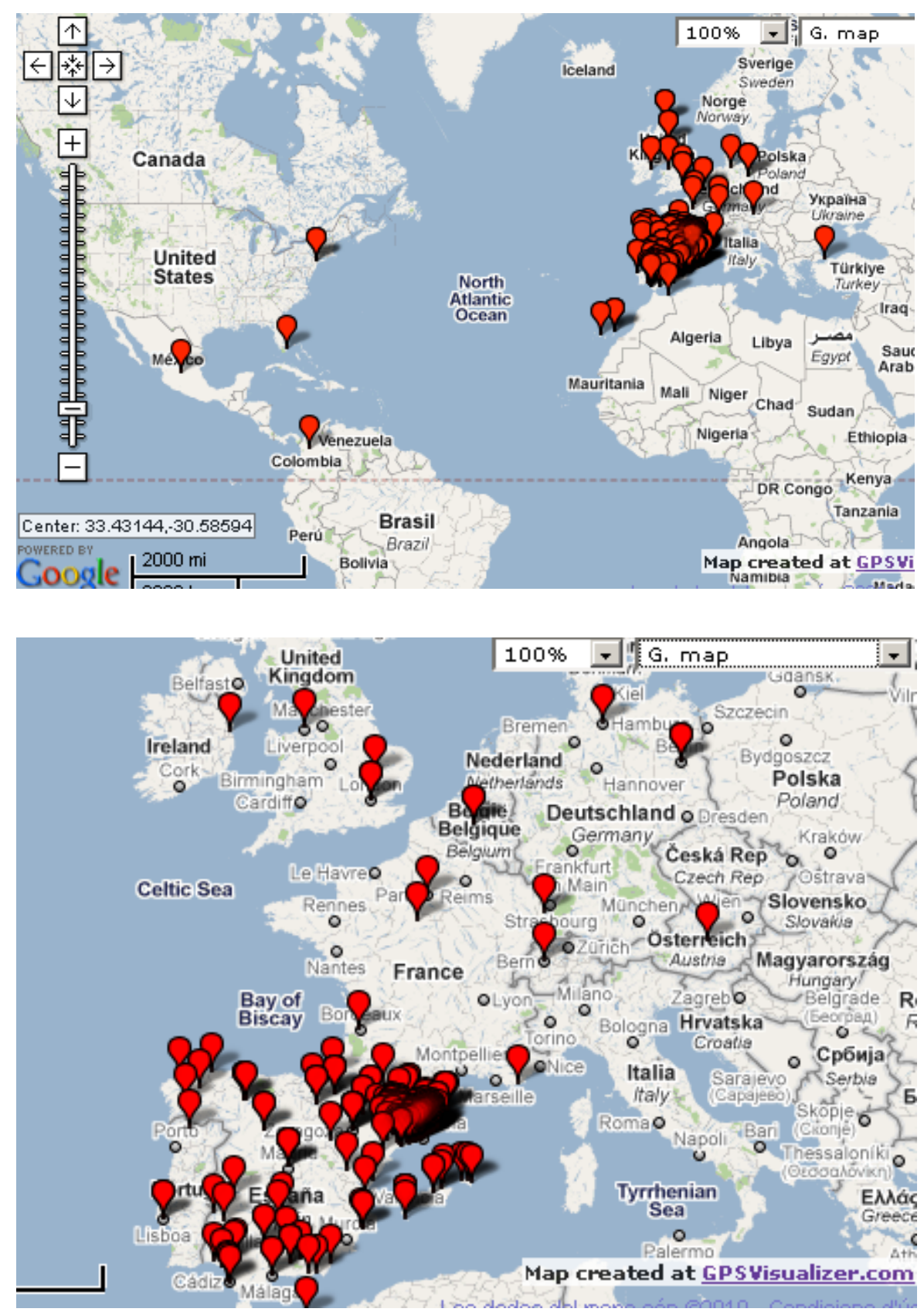

Figure 1. Distribution of non-local active contacts of target group 4 (Non-local active contacts, $35 \%)$. The pins show different localities.

For Ecuadorians, the situation is very different (see Figure 2). First, the active contacts are distributed in a truly "transnational field" (Levitt \& Glick Schiller, 2004), 
Número 1, febrero 2012. No 01/01.

from Europe to America having different countries as destination migration places. Second, the proportion of non-local active contacts is higher (51\%). Ecuadorians are a relatively recent migration group (In our sample, $M=7,7$ years of residence, $S D=$ 2,6 ) that had a fast growth during the 90 s because the special agreements between Spain and Ecuador among other factors (Bretón et al., 2007). Now (2010), some of them are coming back to Ecuador because of the economic crisis and the bilateral plans for facilitating the remigration process ${ }^{5}$.

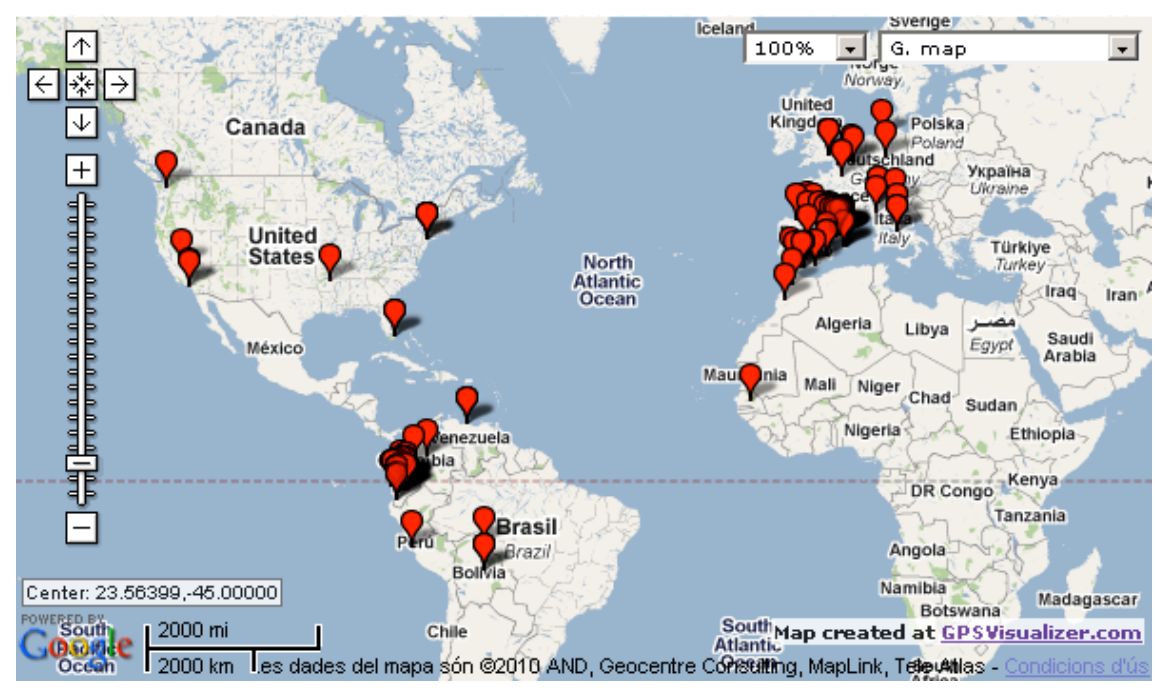

\footnotetext{
${ }^{5}$ http://www.migranteecuatoriano.gov.ec/content/view/2066/522/ [Retrieved: 7-08-2010].
} 
Número 1, febrero 2012. No 01/01.
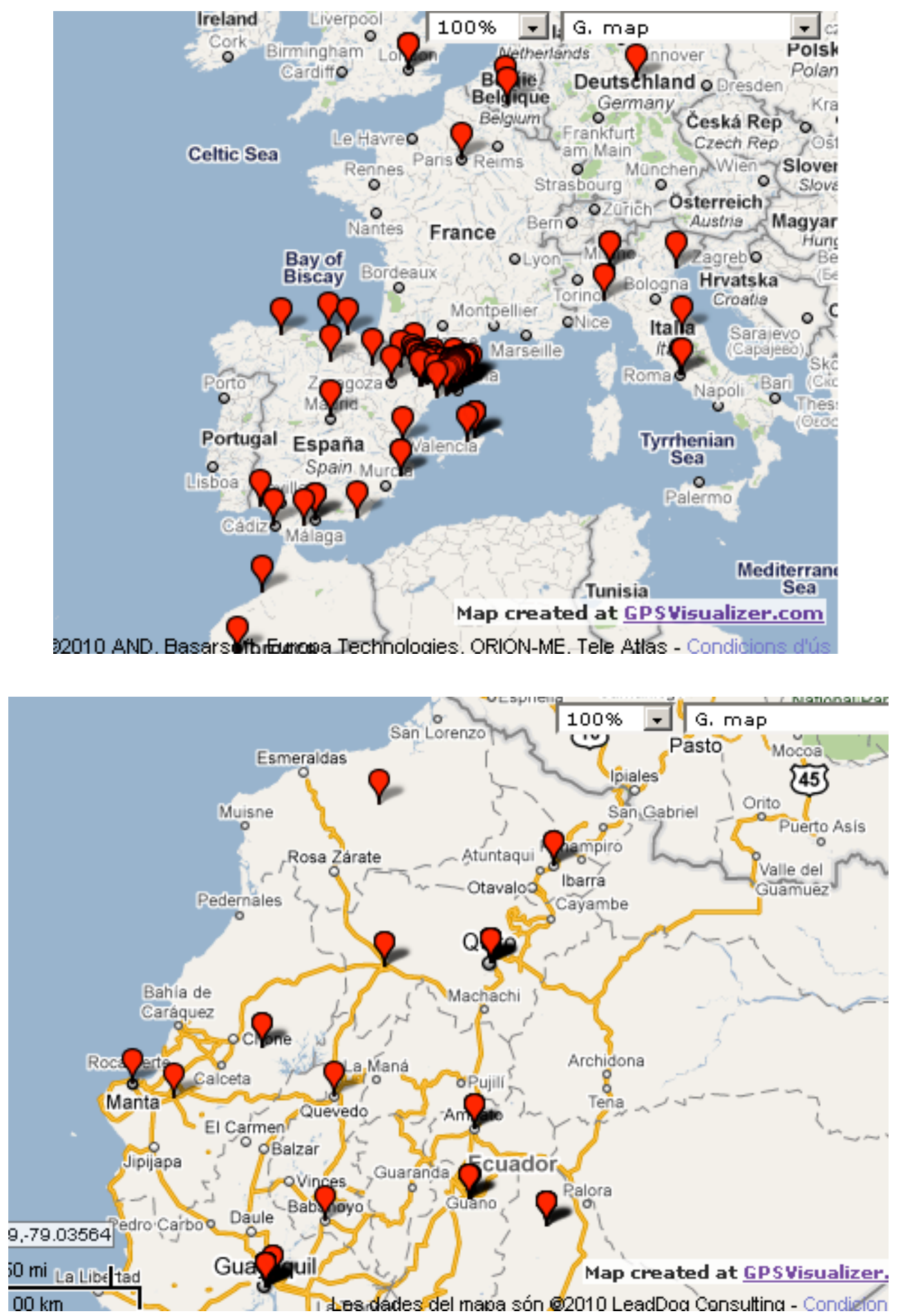

Figure 2. Distribution of non-local active contacts of people born in Ecuador (non-local active contacts, $51 \%)$. 
Número 1, febrero 2012. No 01/01.

Finally, in the case of Moroccans the proportion of non-local active contacts raises to $58 \%(M=7,3, S D=6,3)$.
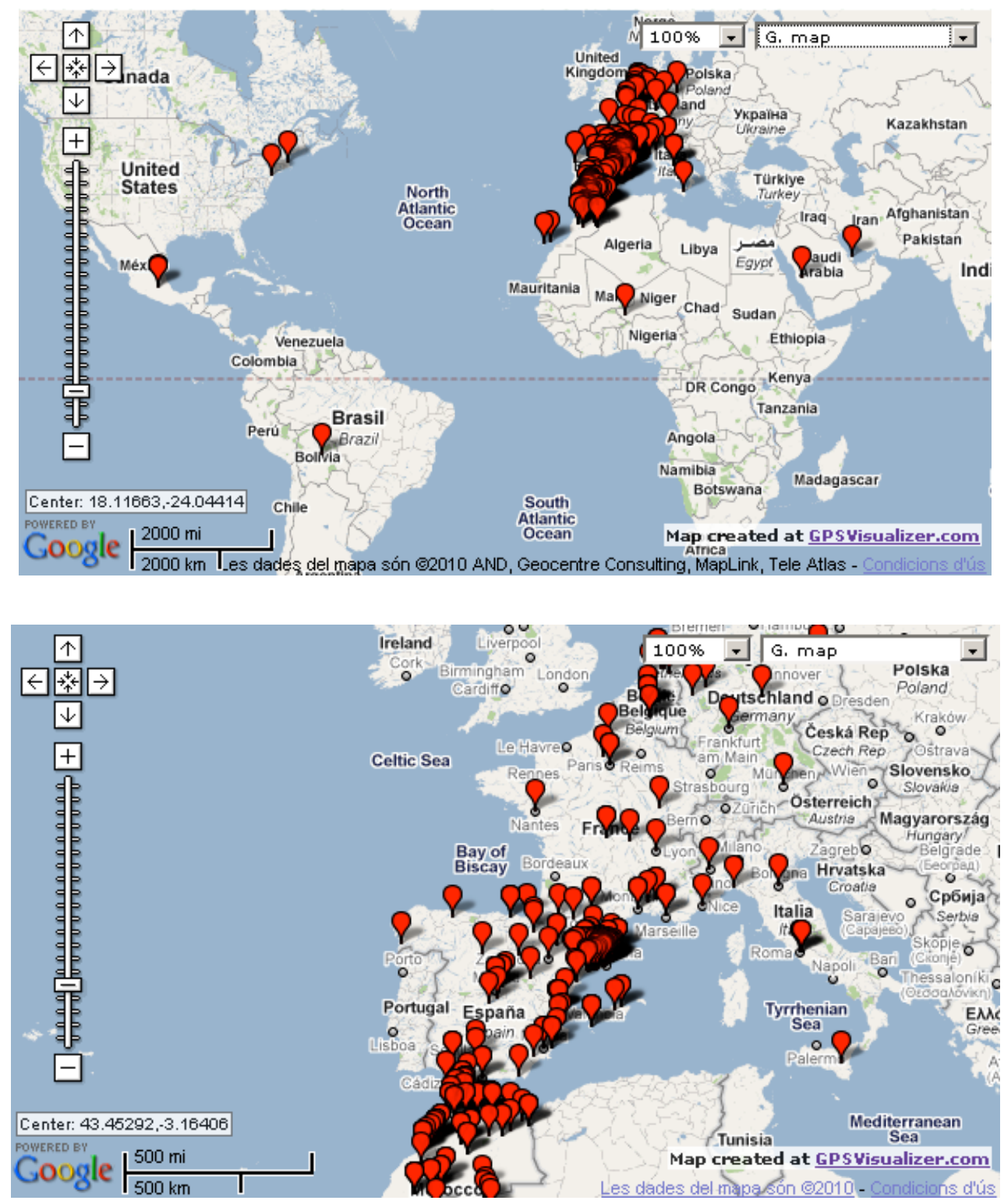


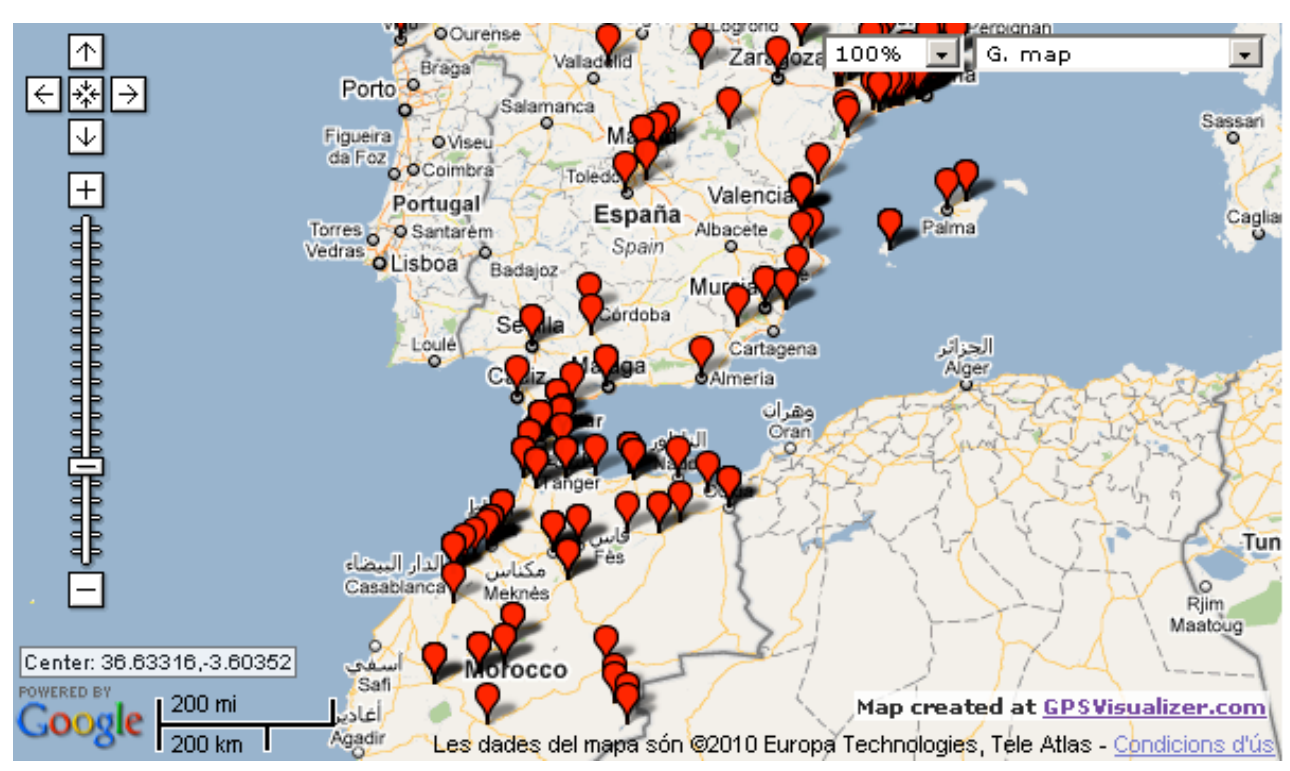

Figure 3. Distribution of non-local active contacts of people born in Morroco (non-local active contacts, $58 \%)$.

The distribution of active contacts follows the path of migration chains, through the Spanish "Levante" (the Mediterranean coast) until different destinations in Western Europe (e.g., France, Italy, The Netherlands; see Figure 3). The proportion of contacts in Morroco is also very high reflecting the importance of visits to the country of origin and the existence of new marriages (Molina et al. 2008).

When we focused on the social interactions among nationals and immigrants, we observed a segregated landscape where intra-ethnic relationships are dominant. Nationals interact mostly with other nationals and the two migrant groups also interact predominantly with co-ethnics (see Table 5 / Figure 4). Of all the active contacts of Spaniards, $97 \%$ were with other Spaniards. This percentage is considerable given that $16 \%$ of the Catalan population are foreign-born. On the other hand, massive immigration is only a very recent phenomenon in Catalonia, and Spain in general, and it can be expected that such developments lead to changes in social networks with some inertia. In 2000 , only $3 \%$ of the Catalan population was foreign-born, a percentage that corresponds with the interactions of Spaniards 
Número 1, febrero 2012. No 01/01.

nowadays. The percentage of intra-ethnic relationships is $73 \%$ for Moroccans and $72 \%$ for Ecuadorians.

\begin{tabular}{|c|c|c|c|c|c|c|}
\hline \multirow{2}{*}{\multicolumn{2}{|c|}{ Origin of Ego }} & \multicolumn{4}{|c|}{$\begin{array}{l}\text { Alters Origin (Spain, Ecuador, Morocco, Other } \\
\text { Country) }\end{array}$} & \multirow[b]{2}{*}{ Total } \\
\hline & & $\begin{array}{l}\text { Born in } \\
\text { Catalonia - } \\
\text { Spain }\end{array}$ & $\begin{array}{c}\text { Born in } \\
\text { Morocco }\end{array}$ & $\begin{array}{l}\text { Born in } \\
\text { Other } \\
\text { Country }\end{array}$ & $\begin{array}{l}\text { Born in } \\
\text { Ecuador }\end{array}$ & \\
\hline \multirow{2}{*}{$\begin{array}{l}\text { Born in Catalonia } \\
\text { Spain }\end{array}$} & $\mathrm{N}$ & 8.430 & 17 & 271 & 12 & 8.730 \\
\hline & $\%$ & $91,8 \%$ & $1,0 \%$ & $49,3 \%$ & $1,0 \%$ & $69,1 \%$ \\
\hline \multirow[t]{2}{*}{ Born in Ecuador } & N & 309 & 29 & 147 & 1.225 & 1.710 \\
\hline & $\%$ & $3,4 \%$ & $1,8 \%$ & $26,7 \%$ & $97,5 \%$ & $13,5 \%$ \\
\hline \multirow[t]{4}{*}{ Born in Morocco } & $\mathrm{N}$ & 444 & 1595 & 132 & 19 & 2190 \\
\hline & $\%$ & $4,8 \%$ & $97,2 \%$ & $24,0 \%$ & $1,5 \%$ & $17,3 \%$ \\
\hline & Total & 9.183 & 1641 & 550 & 1.256 & 12.630 \\
\hline & $\%$ & $100,0 \%$ & $100,0 \%$ & $100,0 \%$ & $100,0 \%$ & $100,0 \%$ \\
\hline
\end{tabular}

Table 5. Distribution of active contacts by origin Ego-Alter. 
Número 1, febrero 2012. No 01/01.

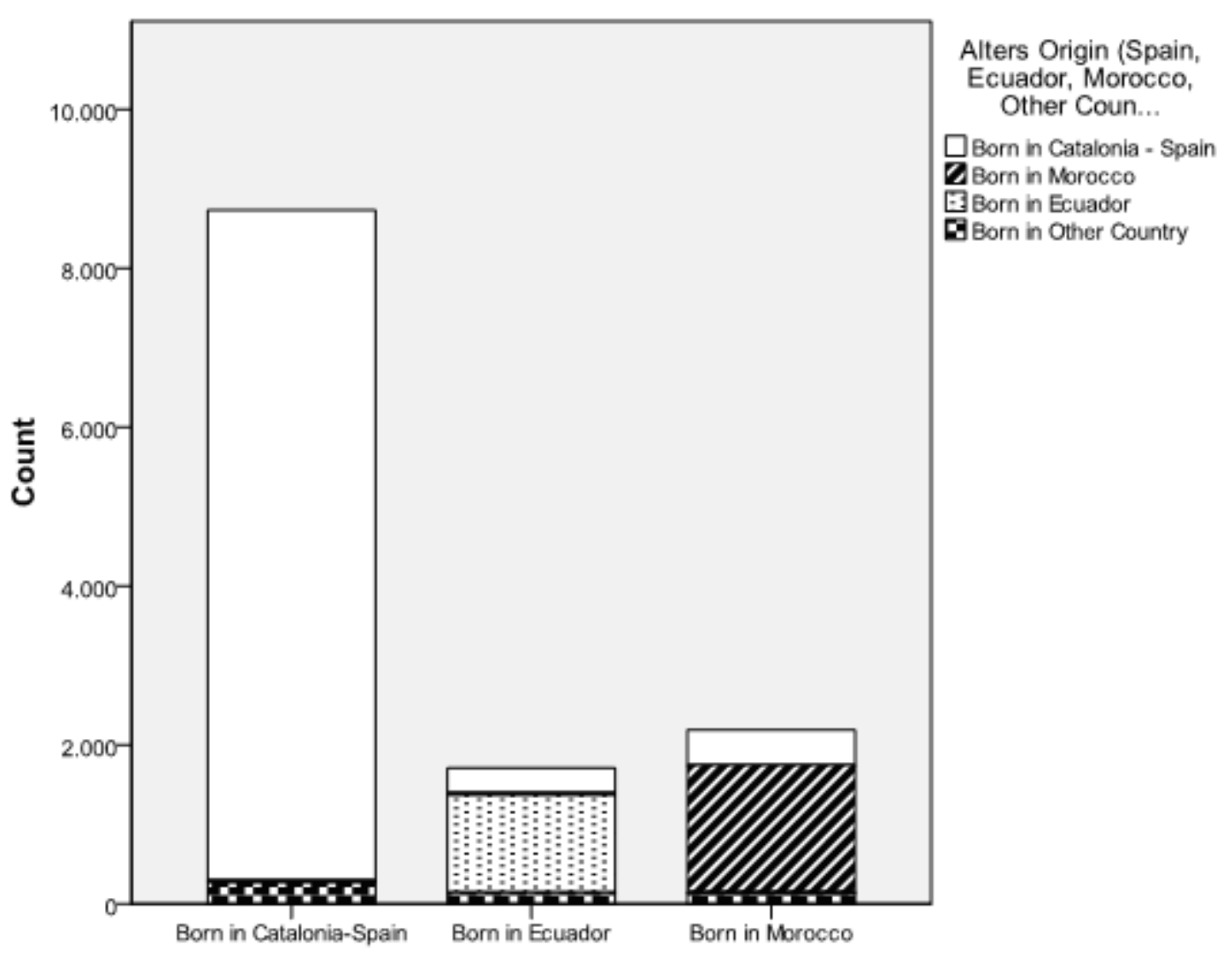

Figure 4. Ego-Alters origin.

\section{Location of alters providing support}

Now, we can understand better why migrants have less active contacts in the neighbourhoods, measured as the proportion of active contacts living in the same locality. Nationals have a mean of $26 \%$ of their contacts living nearby whereas this mean is $17 \%$ for immigrants (there are no gender differences), although in the latter case the concentration in cheaper neighbourhoods can be larger.

When we selected alters who provided at least one type of social support to ego (housing, money, job information, etc.), we also found significant differences among nationals and immigrants $\left(x^{2}=371,05, d f=2, p<.001 ; N=7,735\right.$, see Table 4): the majority of the support providers of nationals live in the same locality, while in the case of immigrants, most of the alters who provide support live in another city. 
Número 1, febrero 2012. No 01/01.

\begin{tabular}{|c|c|c|c|c|c|c|}
\hline \multicolumn{7}{|c|}{ Place of residence alters providing support - origen Eqo } \\
\hline & & & \multicolumn{3}{|c|}{ origen_ego } & \multirow[t]{2}{*}{ Total } \\
\hline & & & Catalonia & Spain & Other & \\
\hline \multirow{4}{*}{$\begin{array}{l}\text { Place of } \\
\text { residence }\end{array}$} & \multirow[t]{2}{*}{ Same dity } & $\mathrm{N}$ & 1782 & 1796 & 1190 & 4768 \\
\hline & & $\%$ & $70,7 \%$ & $67,5 \%$ & $46,6 \%$ & $61,6 \%$ \\
\hline & \multirow[t]{2}{*}{ Other city } & $\mathrm{N}$ & 737 & 866 & 1364 & 2967 \\
\hline & & $\%$ & $29,3 \%$ & $32,5 \%$ & $53,4 \%$ & $38,4 \%$ \\
\hline \multirow{2}{*}{\multicolumn{2}{|c|}{ Total }} & $\mathrm{N}$ & 2519 & 2662 & 2554 & 7735 \\
\hline & & $\%$ Origin & $100,0 \%$ & $100,0 \%$ & $100,0 \%$ & $100,0 \%$ \\
\hline
\end{tabular}

\begin{tabular}{|l|r|rr|}
\hline \multicolumn{4}{|c|}{ Test chi-square } \\
\hline & Valor & gl & $\begin{array}{c}\text { Sig. } \\
\text { asintótica } \\
\text { (bilateral) }\end{array}$ \\
\hline Chi-square de Pearson & $371,051^{\text {a }}$ & 2 &, 000 \\
\hline $\begin{array}{l}\text { Razón de } \\
\text { verosimilitudes }\end{array}$ & 367,404 & 2 &, 000 \\
$\begin{array}{l}\text { Asociación lineal por } \\
\text { lineal }\end{array}$ & 313,830 & 1 &, 000 \\
\hline N de casos válidos & 7735 & & \\
\hline $\begin{array}{l}\text { a. 0 casillas (,0\%) tienen una frecuencia esperada inferior a 5. } \\
\text { La frequencia minim a esperada es 966,24. }\end{array}$ \\
\hline
\end{tabular}

Table 4. Place of residence of alters providers of social support.

\section{Conclusion and discussion}

In this article, we showed that the personal networks of native-born inhabitants of Catalonia were predominantly local, whereas the networks of foreign-born residents reflected a transnational space. This observation was similar when we only selected the network contacts who provided social support. The situation, where immigrants have more active contacts living outside the country, and less social support locally available, is particularly serious as the economic crisis has affected this group more severely: Two years before the survey, the unemployment rate was $6 \%$ among immigrants (compared to $3 \%$ among nationals) and during the data collection this rate raised to $31 \%$ (compared to $18 \%$ for nationals, IDESCAT, 2009).

Apart from the economic situation and focusing on the social interactions among nationals and immigrants, we observed a segregated social landscape where intraethnic relationships are dominant. Nationals interact mostly with other nationals and the two migrant groups also interacted predominantly with co-ethnics (see Table 5). Moreover, the place of meeting people from different ethnic origins is basically the workplace. This striking reality leads us to characterize the Catalan society as a "dual society", where the divide between "nationals" and "migrants" is obvious and where 
Número 1, febrero 2012. No 01/01.

migrants have to rely on ethnic social networks for making a living. These social networks are weaker than those of nationals due to the migration process.

This finding can be explained in terms of the "sub-functional class" (Galbraith, 1992) that is working in a "dual labour market" (Piore, 1972). This sub-functional class does the worst jobs and is constituted basically by immigrants. The core labour market is occupied by the nationals with higher salaries and better working conditions, who can therefore cope better with the current economic crisis.

Although the situation depicted here is clear (ethnic segregation, dual job system, social vulnerability of immigrants), we should make some caveats. First, the quota sample does not allow us to generalise our conclusions to the global Catalan population. We think that the results we presented are a good starting point for widening the sample and creating a sound basis for generalising. Second, the proportion of non-locals is sensitive to the level of education (Grossetti, 2006) so new samples should be selected in order to assess the extent of this effect. Third, other important migrant groups (as Romanians, who represent the second largest foreignborn group in Catalonia, and the third in the province of Barcelona; European Union citizens) should be included in the sample in order to have a better understanding of the situation. Previous research (Lubbers et al. 2010) showed that Argentineans, with a higher average level of education than the migrant groups studied here, had a larger proportion of Spaniards in their networks, so this factor should be also taken into account for a better overview of the Catalan society as a whole.

\section{References}

Axhausen, K.W. (2008). Social networks, mobility biographies, and travel: Survey challenges. Environment and Planning B-Planning \& Design, 35(6), 981-996.

Brandes, U., Kenis, P., \& J. Raab (2006). Explanation Through Network Visualization. Methodology 2(1),16-23.

Bretón, V., García, F., Jové, A. \& M. J. Vilalta (eds.) (2007). Ciudadanía y exclusión: Ecuador y España frente al espejo. Madrid: Catarata. 
Número 1, febrero 2012. No 01/01.

Carrasco, J. A., Hogan, B., Wellman, B., \& E. J. Miller (2008). Agency in Social Activity Interactions: The Role of Social Networks in Time and Space. Tijdschrift voor economische en sociale geografie, 99 (5), 562 - 583.

Chen, Y. D., Tseng, C. J., King, C. C., Wu, T. S. J., \& Chen, H. C. (2007). Incorporating geographical contacts into social network analysis for contact tracing in epidemiology: A study on Taiwan SARS data. Intelligence and Security Informatics: Biosurveillance, Proceedings, 4506, 23-36.

Fischer, C. (1982). To Dwell Among Friends. Personal Networks in Town and City. Chicago: University of Chicago Press.

Fischer, C. S. \& Y. Shavit (1995). National differences in network density: Israel and the United States. Social Networks, 17 (2), 129-145.

Frändberg, L. (2008). Paths in transnational time-space: representing mobility biographies of young Swedes. Geogr. Ann. B 90 (1): 1-28.

Galbraith, J. K. (2000). La cultura de la satisfacción [The Culture of the Contentment, 1992]. Barcelona: Ariel.

Girardin, F. (2009). Aspects of implicit and explicit human interactions with ubiquitous geographic information. Unpublished doctoral thesis, July, UPF, Barcelona.

Glückler, J. (2007). Economic geography and the evolution of networks. Journal of Economic Geography, 7, 619-634.

Grossetti, M. (2006). La ville dans l'espace des réseaux sociaux. In M. Bonnet \& $P$. Aubertel (Eds.), La ville aux limites de la mobilité. Paris: Presses Universitaires de France, pp.83-90.

Grossetti, M. (2007). Are French networks different? Social Networks, 29 (3), 391404.

Hampton, K., \& B. Wellman (2002). "The Not So Global Village of Netville." Pp. 345371 in The Internet in Everyday Life. Oxford: Blackwell.

IDESCAT (2009). Foreign population. Retrieved July $15^{\text {th }}$, 2010, from http://www.idescat.cat/poblacioestrangera/?lang=en 
Número 1, febrero 2012. No 01/01.

Lambiotte, R., Blondel, V. D., De Kerchove, C., Huens, E., Prieur, C., Smoreda, Z., \& P. Van Dooren (2008). Geographical dispersal of mobile communication network. arXiv:0802.2178v2 [physics.soc-ph] .

Larsen, J., Urry, J., Axhausen, K., (2006). Mobilities, Networks, Geographies. Ashgate, Aldershot.

Levitt, P. \& N. Glick Schiller (2004). Conceptualizing Simultaneity: A Transnational Social Field Perspective on Society. International Migration Review, 38, (3), Conceptual and Methodological Developments in the Study of International Migration (Fall), pp. 1002-1039.

Liben-Nowell, D., Novak, J., Kumar, R., Raghavan, P., \& Tomkins, A. (2005). Geographic routing in social networks, Proc.Natl.Acad.Sci.U.S.A., 10, 33 (1162311628).

Licoppe, C., Diminescu, D., Smoreda, Z., \& Ziemlicki,C. (2008). Using mobile phone geolocalisation for 'socio-geographical' analysis of co-ordination, urban mobilities, and social integration patterns. Tijdschrift Voor Economische En Sociale Geografie, 99(5), 584-601.

Lozares, C.; J. M. Verd, P. López-Roldán, J. Martí \& J. L. Molina (2011). "Cohesión, Vinculación e Integración sociales como formas de Capital social", Revista REDES vol. 20 \#1 (http://revista-redes.rediris.es).

Lubbers M. J., J. L. Molina, J. Lerner, U. Brandes, C. McCarty \& J. Ávila (2010). Longitudinal analysis of personal networks. The case of Argentinean migrants in Spain. Social Networks, 31 (5)..

McCarty, C. (2002). "Structure in Personal Networks", JoSS. <http://www.cmu.edu/joss/content/articles/volume3/McCarty.html> [Retrieved: 2-0608].

Molina, J. L., I. Maya-Jariego \& C. McCarty, in press. Giving Meaning to Social Networks: Methodology for Conducting and Analyzing Interviews based on Personal Network Visualizations. In B. Hollstein \& S. Dominguez (eds.), Mixing methods in social network research, Cambridge University Press. 
Número 1, febrero 2012. No 01/01.

Molina, J. L.; Lerner, J. \& S. Gómez Mestres (2008). "Patrones de cambio de las redes personales de inmigrantes en Cataluña", REDES-Revista hispana para el análisis de redes sociales, Volumen 15 \#4 (36-60).

Obbo, C. (1993). .HIV transmission through social and geographical networks in Uganda. Social Science \& Medicine, 36 (7),949-955.

Onnela J.P., Saramäki J., Hyvönen J., Szabó G., Lazer D., Kaski K., Kertész J.,Barabási A.L. (2007). Structure and tie strengths in mobile communication networks. Proc Natl Acad Sci, 104(18):7332-6.

Piore, M. J. (1971). The Dual Labor Market. Theory and Implications. In D. M. Gordon (ed.), Problems in Political Economy: An Urban perspective. Lexington: DC Heath.

Urry, J. (2010). "Mobile Sociology", The British Journal of Sociology, 347-366.

Wellman, B. (1979). The Community Question: The Intimate Networks of East Yorkers. The American Journal of Sociology, 84(5), 1201-1231.. 